\section{Analysis of Powdery Mildew-resistant Dogwood Accessions Using AFLP}

\author{
Margaret T. Mmbaga \\ Otis Floyd Nursery Crop Research Station, 472 Cadillac Lane, McMinnville, \\ TN 37110
}

\author{
Roger J. Sauvé ${ }^{1}$ \\ Institute of Agriculture and Environmental Research, Tennessee State \\ University, 3500 J.A. Merritt Boulevard, Nashville, TN 37209-1531
}

Additional index words. Cornus florida, C. kousa, C. kousa $\times$ C. florida, Erysiphe (Sect. Microsphaera) pulchra

\begin{abstract}
Twenty-five dogwood accessions (one Cornus kousa, three $C$. kousa $\times$. florida hybrids, and 21 . florida) were characterized using amplified fragment length polymorphism. Among the $C$. florida accessions, four were named cultivars and 17 were selections from Tennessee State University's dogwood breeding program. Amplified fragment length polymorphism band profiles obtained from $13 \mathrm{EcoRI} / \mathrm{MseI}(+3 /+3)$ primer pairs showed the presence of high genetic diversity between species and within the C. florida accessions. Each accession was distinctly different from each other, and the resistant clones clustered into distinct groups.
\end{abstract}

Powdery mildew is the most serious disease that affects flowering dogwood (Cornus florida L.) in the southeastern United States. Currently, only two powdery mildewresistant cultivars are available commercially: 'Cherokee Brave' and 'Fragrant Cloud' (Mmbaga and Sauvé, 2004b). However, most Japanese dogwood (C. kousa) cultivars and most Japanese interspecific hybrids (C. kousa $\times$ C. florida) are resistant (Mmbaga and Sauvé, 2004b). Current disease management practices for this disease relies on the routine application of fungicide (Mmbaga and Sauvé, 2004a, b).

Polymerase chain reaction (PCR)-based techniques have been used extensively for the identification of molecular markers in plants (Sauvé et al., 2005; Wechter et al., 1995; Weising et al., 1995; Welsh and McClelland, 1990; Zhou and Sauvé, 2002, 2006). The amplified fragment length polymorphism (AFLP) technique is one of the most reliable methods for genomic analysis (Jiang et al., 2000; Vos et al., 1995; Zhou and Sauvé, $2002,2006)$. The objective of this study was to characterize 12 of our 35 most horticultural desirable powdery mildew-resistant clones using AFLP markers and to compare the relationships between resistant and susceptible cultivars.

\section{Materials and Methods}

Plant material preparation. Twenty-five dogwood selections that were previously characterized for powdery mildew resistance/susceptibility were used for this study (Mmbaga and Sauvé, 2004b). They included four clones of named $C$. florida cultivars, one C. kousa, three C. kousa $\times$ florida hybrids, and $17 C$. florida selections collected in the wild. Of the wild selections, 12 were resistant and five were susceptible to powdery mildew (Table 1).

DNA extraction and analysis. DNA was isolated from terminal bud tissue collected from each plant using a DNeasy Plant Mini Extraction Kit (QIAGEN, Santa Clara, Calif.). The presence of DNA was verified in a $2 \%$ agarose gel and concentrations were quantified using a Hoechst dye-based fluorometer (Hoefer Scientific Instruments, San Francisco, Calif.). AFLP-based fragments were generated via PCR using an AFLP System-Analysis Kit (Invitrogen ${ }^{T M}$ Life Technologies, Carlsbad, Calif.) with EcoRI/ MseI primer pairs.

DNA templates were prepared by the digestion of $20 \mathrm{ng} \cdot \mu \mathrm{L}^{-1}$ genomic DNA with EcoRI and MseI restriction enzymes at $37^{\circ} \mathrm{C}$ for $3 \mathrm{~h}$ and confirmed in agarose gels. Restriction fragments were ligated for $3 \mathrm{~h}$ at $37{ }^{\circ} \mathrm{C}$ to EcoRI/MseI adapters. The ligation mixture was diluted 10 -fold with sterile distilled water, and fragments were preamplified using $30 \mathrm{PCR}$ cycles of $94^{\circ} \mathrm{C}$ for $30 \mathrm{~s}$, $56{ }^{\circ} \mathrm{C}$ for $60 \mathrm{~s}$, and $72{ }^{\circ} \mathrm{C}$ for $60 \mathrm{~s}$ using Life Technologies' primers in the preamplified primer mix (Vos et al., 1995). Preselective amplifications were performed in a Techne Progene $^{T M}$ (Princeton, N.J.) thermal cycler. Selective primers were obtained from Life Technologies. Preliminary experiments with $E c o R I+$ three bases and MseI + three bases resulted in the generation of many polymorphic DNA fragments. A total of 18 selective EcoRI /MseI $(+3 /+3)$ primer pairs $(\mathrm{E}-\mathrm{AAC} /$ M-CAA, E-AAC /M-CAC, E-AAC/M-CAG, E-AAC/M-CAT, E-AAG/M-CAC, E-AAG/ M-CAT, E-AAG/M-CTA, E-ACA/M-CAC,
Table 1. Dogwood accessions used in AFLP analysis and their reaction to powdery mildew in previous studies.

\begin{tabular}{|c|c|c|c|}
\hline Cornus species & $\begin{array}{l}\text { Cultivar names } \\
\text { and selections }\end{array}$ & County of origin & $\begin{array}{l}\text { Powdery mildew } \\
\text { reaction }^{\mathrm{y}}\end{array}$ \\
\hline C. florida & Purple Glory & Named cultivar & $\mathrm{S}$ \\
\hline C. florida & Ozark Spring & Named cultivar & $\mathrm{S}$ \\
\hline C. florida & Cherokee Princess & Named cultivar & $\mathrm{S}$ \\
\hline C. florida & Rainbow & Named cultivar & $\mathrm{S}$ \\
\hline C. kousa & Milky Way & Named cultivar & $\mathrm{R}$ \\
\hline \multirow[t]{17}{*}{ C. florida selections } & MI-2 & Coffee County, Tenn. & $\mathrm{R}$ \\
\hline & MI-6 & Coffee County, Tenn. & $\mathrm{R}$ \\
\hline & MI-5 & Coffee County, Tenn. & $\mathrm{R}$ \\
\hline & RN3 & Dekalb County, Tenn. & $\mathrm{R}$ \\
\hline & RN20 & Dekalb County, Tenn. & $\mathrm{R}$ \\
\hline & RN9 & Dekalb County, Tenn. & $\mathrm{R}$ \\
\hline & RN6 & Dekalb County, Tenn. & $\mathrm{R}$ \\
\hline & RN13 & Dekalb County, Tenn. & $\mathrm{R}$ \\
\hline & RN23 & Dekalb County, Tenn. & $\mathrm{R}$ \\
\hline & WR16 & Warren County, Tenn. & $\mathrm{R}$ \\
\hline & WR19 & Warren County, Tenn. & $\mathrm{R}$ \\
\hline & WR20 & Warren County, Tenn. & $\mathrm{R}$ \\
\hline & HL10 & Warren County, Tenn. & $\mathrm{S}$ \\
\hline & HL26 & Warren County, Tenn. & S \\
\hline & HL38 & Warren County, Tenn. & $\mathrm{S}$ \\
\hline & RN16 & Dekalb County, Tenn. & $\mathrm{S}$ \\
\hline & RN1 & Dekalb County, Tenn. & $\mathrm{S}$ \\
\hline \multirow{3}{*}{$\begin{array}{l}\text { C. florida } \times \text { C. kousa } \\
\text { hybrids }\end{array}$} & Constellation & Named cultivar & $\mathrm{R}$ \\
\hline & Ruth Ellen & Named cultivar & MR \\
\hline & Stellar Pink & Named cultivar & $\mathrm{R}$ \\
\hline
\end{tabular}

Received for publication 15 June 2006. Accepted for publication 12 Sept. 2006.

This research was partially funded by a U.S. Department of Agriculture Capacity Building Grant (TENX-2002 38814-12721) and a grant from The Horticultural Research Institute.

The authors thank Drs. Naseer Aziz and Suping Zhou for critical review of the manuscript.

${ }^{1}$ To whom all reprint requests should be addressed; e-mail rsauve@tnstate.edu

${ }^{2}$ The unnamed accessions were selected from wild populations at different locations in Tennessee. Accessions with the same letter in their ID number are from the same location ( RN = Dekalb county, WR and $\mathrm{HL}=$ Warren County, and $\mathrm{MI}=$ Coffee County).

${ }^{\mathrm{y}} \mathrm{S}$, susceptible; MR, moderately resistant; R, resistant (Mmbaga and Sauvé, 2004b). 
Table 2. AFLP markers produced by 13 selected primer pairs among dogwood accessions and percent polymorphism reflecting the number of total bands from each primer that distinguished at least one accession.

\begin{tabular}{lcccc}
\hline & $\begin{array}{c}\text { No. of bands } \\
\text { obtained }\end{array}$ & $\begin{array}{c}\text { Range in } \\
\text { band size (bp) }\end{array}$ & $\begin{array}{c}\text { Polymorphism, } \\
\text { strong or weak }\end{array}$ & $\begin{array}{c}\text { No. of bands } \\
\text { used in AFLP } \\
\text { analysis }\end{array}$ \\
\hline E-AAC/M-CAA & 23 & $85-300$ & $++(-4)$ & 0 \\
E-AAC/M-CAC & 42 & $100-350$ & $++++(-3)$ & 42 \\
E-AAC/M-CAG & 29 & $100-425$ & $+++(-3)$ & 18 \\
E-AAC/M-CAT & 18 & $100-300$ & + & 20 \\
E-AAG/M-CAC & 20 & $85-300$ & $+++(-2)$ & 41 \\
E-AAG/M-CTA & 41 & $100-390$ & $+++(-3)$ & 32 \\
E-ACA/M-CAC & 40 & $110-500$ & $+++(-5)$ & 21 \\
E-ACC/M-CAC & 18 & $100-300$ & + & 18 \\
E-ACA/M-CTC & 33 & $135-450$ & +++ & $+++(-2)$ \\
E-ACC/M-CTA & 21 & $100-400$ & $+++(-2)$ & 23 \\
E-ACC/M-CTT & 20 & $100-400$ & $++(-4)$ & 25 \\
E-ACG/M-CTT & 24 & $117-475$ & $++(-4)$ & 20 \\
E-ACT/M-CAC & 18 & $100-400$ & $+++(-1)$ & 260 \\
E-ACT/M-CAT & 25 & $115-410$ & $+++(-2)$ & $+++(-3)$ \\
E-ACT/M-CAG & 27 & $100-400$ & & \\
E-AGG/M-CTG & 26 & $70-400$ & & \\
Total & 425 & & & \\
\hline
\end{tabular}

${ }^{\text {zPolymorphism was considered strong or weak on the basis of very strong bands on all accessions }(++++)}$ or very weak bands $(+)$. Some genotypes did not show any bands with the particular primer pair and the negative numbers indicate the number of accessions that did not show any bands after the analysis was repeated three times.

M $1234567891011121314151617181920212223242526 \mathrm{M}$

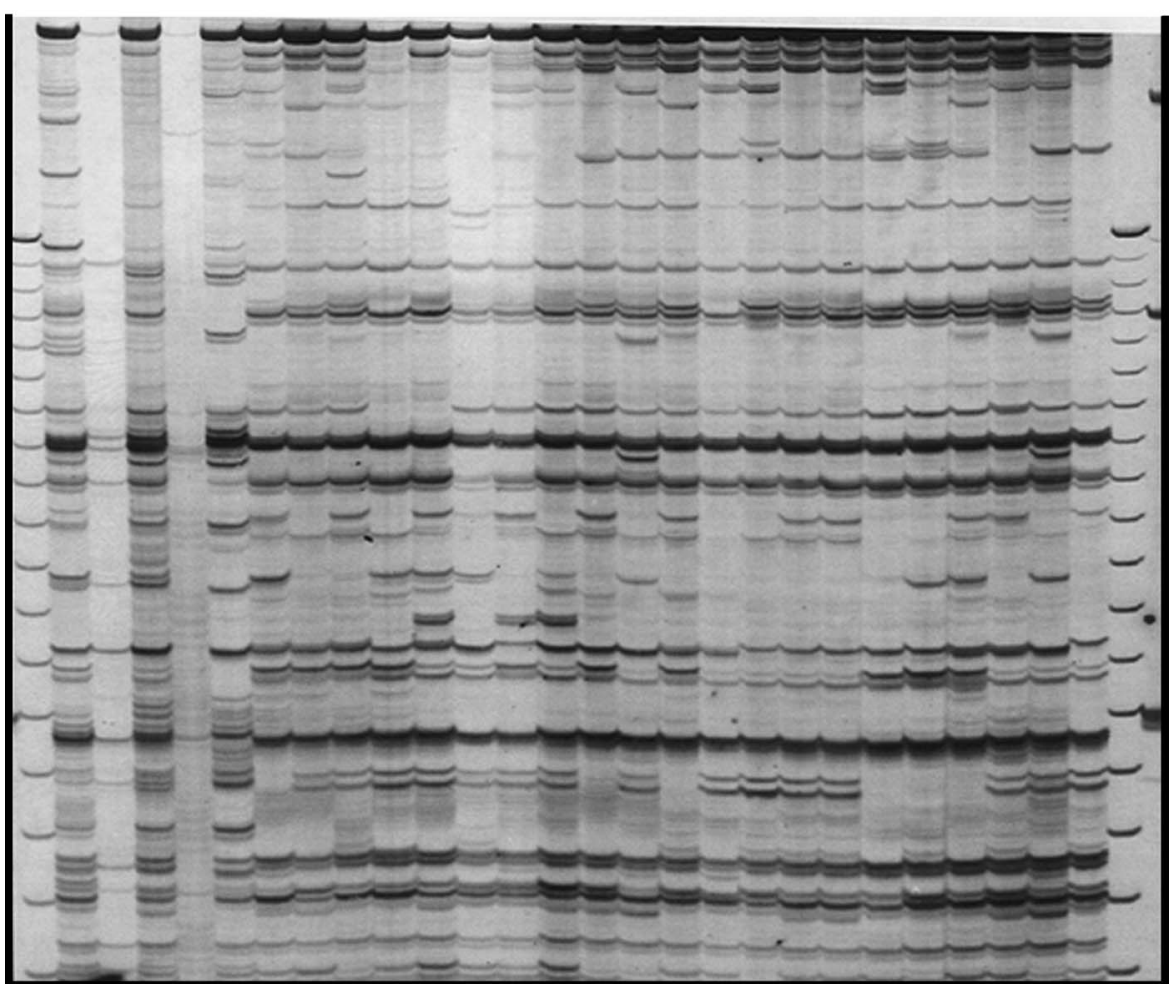

Fig. 1. Polymorphism detected by AFLP analysis using the selective primer pair E-ACC/M-CTT on 25 dogwood genotypes. Lane labels: M, 100 bp molecular marker; lanes 1 to 3 and 25, C. kousa $\times$ C. florida hybrids; 1 and 26, 'Stellar Pink'; 2, 'Constellation'; 3, 'Ruth Ellen'; 4, C. kousa 'Milky Way'; lanes 5 to 8 are named $C$. florida cultivars; 5, 'Ozark Spring'; 6, 'Rainbow'; 7, 'Purple Glory'; 8, 'Cherokee Princess'; lanes 9 to 25 are C. florida selections; 9, RN-16; 10, RN-1; 11, HL-38; 12, HL-26; 13, HL-10; 14, RN-13; 15, RN-22; 16, WR-20; 17, WR-19; 18, WR-16; 19, MI-6; 20, MI-5; 21, RN-3; 22, RN-6; 23, RN-9; 24, RN-20; and 25, RN-23.

E-ACA/M-CTC, E-ACA/M-CTT, E-ACC/ M-CTA, E-ACC/M-CTT, E-ACG/M-CTT, E-ACT/M-CAC, E-ACT/M-CAG, E-ACT/ $\mathrm{M}-\mathrm{CAT}, \mathrm{E}-\mathrm{ACT} / \mathrm{M}-\mathrm{CTG}$, and E-AGG/MCTG) were screened on all accessions. Selective PCR was done using amplification temperature of one cycle at $94{ }^{\circ} \mathrm{C}$ for $30 \mathrm{~s}$, $56^{\circ} \mathrm{C}$ for $30 \mathrm{~s}$, followed by 30 cycles at $94{ }^{\circ} \mathrm{C}$ for $30 \mathrm{~s}, 56{ }^{\circ} \mathrm{C}$ for $30 \mathrm{~s}$, and $72{ }^{\circ} \mathrm{C}$ for $60 \mathrm{~s}$. The PCR products were separated by electrophoresis in a denaturing polyacrylamide DNA sequencing gel containing $7.5 \mathrm{~m}$ urea.
The AFLP gel was visualized using the silver staining procedure following Promega's protocol (Madison, Wisc.).

The presence or absence of bands was scored and used to determine the association among genotypes. Only bands with a $65 \%$ brightness level or higher were scored and used in the analysis (Rohlf, 1992). The similarities between different accessions were determined using PHYLIP's Phylogeny Inference Package (version 3.5), the general bootstrap tool SEQBOOT (C) (University of Washington), and the matrix of the genetic distance method described in RAPDistance v1.04 (Armstrong et al., 1996). Euclidean distances were used to generate a tree using the Phylogeny Inference Package program for DRAWGRAM (PHYLIP, version 3.5c Univ. of Washington, Seattle).

\section{Results}

Out of 18 primer pairs, 15 produced polymorphic bands and three produced monomorphic bands. These primer pairs revealed a large number of polymorphic fragments. With each primer pair, between 20 and 42 loci were revealed for each of the 25 dogwood accessions evaluated (Table 2, Fig. 1). AFLP analysis was repeated once with all primer pairs and twice with pairs that had missing data. After three repeats, primer pairs with missing data were discarded. Only 10 primer pairs $(55.5 \%)$ were used to determine the associations among the 25 accessions. Only $61 \%$ of the bands ( 260 ) were used to determine the association between the genotypes (Fig. 2). Most C. florida accessions, with the exception of 'Ozark Spring', grouped together and were distinct from $C$. kousa and the $C$. kousa $\times$ C. florida hybrids, which shared relatively high bootstrap values. Of the $C$. florida accessions, 'Ozark Spring', accessions WR-19 and WR-16 were genetically distinct and distant from each other and from the other $C$. florida accessions and shared low bootstrap values (Fig. 2). Overall, no two accessions were identical; however, most selections that originated at a specific location grouped close to each other (Fig. 2). Accessions MI-2, MI-5, and MI-6 (which originated in Coffee County, Tenn.) grouped closely together (higher bootstrap values); and accessions $\mathrm{RN}-13, \mathrm{RN}-23$, and RN-20 (which originated in Dekalb County, Tenn.) grouped closely together with 'Cherokee Princess', 'Purple Glory', and 'Rainbow'. Such clustering indicated that the three named clones may be related to the new clones from Dekalb County. The C. kousa $\times$ C. florida hybrids 'Celestial', 'Ruth Ellen', and 'Stellar Pink' were all different from each other (with relatively high bootstrap values) and from all other accessions (Fig. 2).

\section{Discussion}

Previous investigators suggested that the genetic diversity in flowering dogwoods was low and that some cultivars were genetically similar (Caetano-Anolles et al., 1991; Windham 


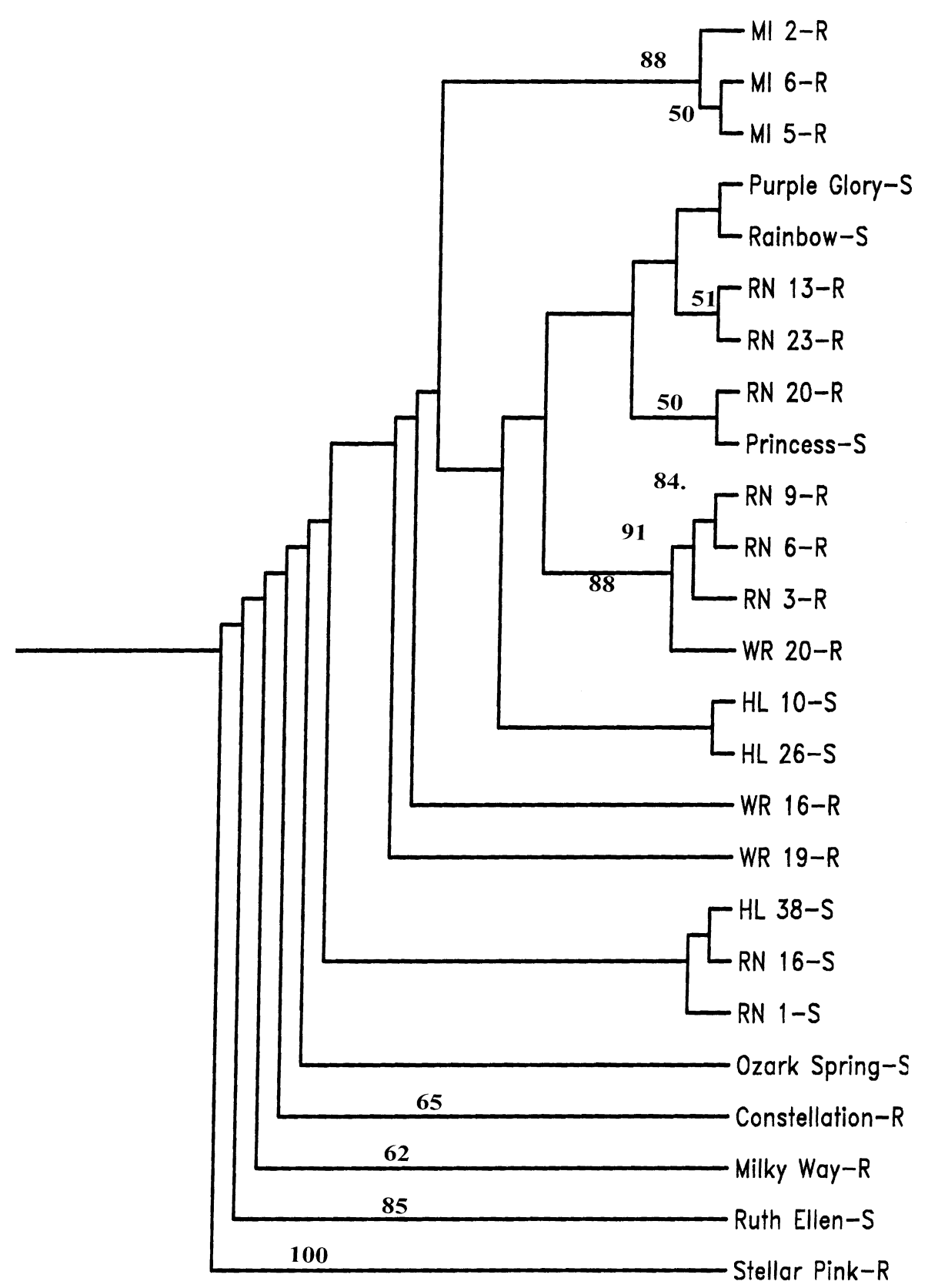

Fig. 2. Phylogenetic analysis of 25 Cornus accessions. The RN selections originated in Dekalb County, whereas WR and HL are from Warren Counties, Tenn. The MI selection, 'Cherokee Princess' and 'Ozark Springs', originated in Coffee County, Tenn. Only bootstrap values $\geq 50 \%$ are shown. R, resistant; S, susceptible.

and Trigiano, 1998). This study indicates that there is a higher level of genetic diversity within the evaluated accessions than was previously believed. All the $C$. florida accessions used in this study were derived from open pollination, and most shared relatively few molecular sequences, as shown by the relatively low bootstrap values.

All our new powdery mildew-resistant selections produce abundant white blooms and are morphologically and phenotypically distinct from 'Cherokee Brave'. Resistant selections MI-5, MI-6, and MI-2 formed a close cluster and are morphologically very similar. Selections RN-13, RN-23, and RN 20 formed another group close to the three named susceptible cultivars ('Purple Glory', phisms could also be used for tracking the genetic inheritance within a progeny (Arnholdt-Schmitt., 2000; Zhou and Sauvé, 2006). If AFLP molecular markers can be linked to disease resistance, plant breeders would be able to identify disease-resistant accessions early during the selection process.

\section{Literature Cited}

Arnholdt-Schmitt, B. 2000. RAPD analysis: A method to investigate aspects of the reproductive biology of Hypericum perforatum L. Theor. Appl. Genet. 100:906-911.

Armstrong, J.S., A.J. Gibbs, R. Peakall, and G. Weiller. 1996. The RAPDistance program, version 1.04 for the analysis of patterns of RAPD fragments. Australia National Univ., Canberra, Australia. <http://www.rsbs.anu. edu.au/Products\&Services/BiotechnologyTransferUnit/rapdistance.asp $>$. Accessed 25 Oct. 2006. <http://life.anu.edu.au/molecular/software/rapd.html $>$;

Caetano-Anolles, G., B.J. Bassam, and P.M. Gresshoff, 1991. High resolution DNA amplification fingerprinting using very short arbitrary oligonucleotide primers. Bio/Technol. 9:553-557.

Jiang, S.C., V. Louis, N. Choopun, A. Sharma, A. Huq, and R.R. Colwell. 2000. Genetic diversity of Vibrio cholerae in Chesapeake Bay determined by amplified fragment length polymorphism fingerprinting. Appl. Environ. Microbiol. 66:140-147.

Mmbaga, M.T. and R.J. Sauvé. 2004a. Management of powdery mildew in flowering dogwood in the field with biorational and conventional fungicides. Can. J. Plant Sci. 84:837-844.

Mmbaga, M.T. and R.J. Sauvé. 2004b. Multiple disease resistance in dogwoods (Cornus spp.) to foliar pathogens. J. Arboricultur. 30:101-106.

Rohlf, F.J. 1992. NTSYS-pc numerical taxonomy and multivariate analysis system, version 1.70 . Exeter Software, Setauket, N.Y.

Sauvé, R.J., S. Zhou, Y. Yu, and W.G. Schmid. 2005. Randomly amplified polymorphic DNA analysis in the genus Hosta. HortScience 40:1243-1245.

Vos, P., R. Hogers, M. Bleeker, M. Reijans, T. vander Lee, M. Jornes, A. Frijters, J. Pot, J. Peleman, M. Kuiper, and M. Zabeau. 1995. AFLP: A new technique for DNA fingerprinting. Nucl. Acids Res. 23:4407-4414.

Wechter, W.P., M.P. Whitehead, C.E. Thomas, and R.A. Dean. 1995. Identification of a randomly amplified polymorphic DNA marker linked to the form2 Fusarium wilt resistance gene in muskmelon MR-1. Phytopathology 85:12451249.

Weising, K., H. Nyborm, K. Wolff, and W. Meyer. 1995. DNA fingerprinting in plants and fungi. CRC Press, Boca Raton, Fla.

Welsh, J.L. and M. McClelland. 1990. Fingerprinting genomes using PCR with arbitrary primers. Nucl. Acids Res. 18:6531-6535.

Windham, M.T. and R.N. Trigiano. 1998. Are 'Barton' and 'Cloud 9' the same cultivar of Cornus florida? J. Environ. Hort. 16:163-168.

Zhou, S. and R.J. Sauvé. 2002. Use of fluorescentamplified fragment length polymorphism for species identification in the genus Pulmonaria. J. Environ. Hort. 20:110-113.

Zhou, S. and R.J. Sauvé. 2006. Genetic fingerprinting of goldenseal (Hydrastis canadensis L [Ranunculaceae]) using AFLP. Native Plants J. 7:72-77. 